\title{
Enhancing adherence to mood charting with an online version of the NIMH Life Chart
}

Daniel Lieberman

From $1^{\text {st }}$ International Congress on Neurobiology and Clinical Psychopharmacology and European

Psychiatric Association Conference on Treatment Guidance

Thessaloniki, Greece. 19-22 November 2009

Longitudinal mood instability is the essential feature of bipolar disorder, however most rating scales are cross sectional in nature, and focus on acute symptoms. By contrast, the NIMH Life Chart Methodology (LCM) characterizes in detail the severity, duration, and frequency of mood episodes. Unfortunately, adherence to daily rating tends to be low. Compared to the traditional paper chart, an online adaptation of the LCM that used links embedded in a daily email as the primary form of data entry substantially increased the number of days rated by a sample of patients with bipolar disorder. An analysis of the ways in which users interacted with the application found that manipulation of the user interface affected the number of days that were rated. Features of video games and commercial web sites designed to reinforce repeated long-term use can be adapted to therapeutic applications to support adherence. These features include content delivery, point accumulation, personalization, discovery, and reward.

Published: 22 April 2010

doi:10.1186/1744-859X-9-S1-S11

Cite this article as: Lieberman: Enhancing adherence to mood charting with an online version of the NIMH Life Chart. Annals of General

Psychiatry 2010 9(Suppl 1):S11.
Submit your next manuscript to BioMed Central and take full advantage of:

- Convenient online submission

- Thorough peer review

- No space constraints or color figure charges

- Immediate publication on acceptance

- Inclusion in PubMed, CAS, Scopus and Google Scholar

- Research which is freely available for redistribution

Submit your manuscript at www.biomedcentral.com/submit
C Biomed Central 